\title{
INTERACTION OF LEARNING MATHEMATICS AND CONSTRUCTIVE ATTITUDES OF STUDENTS ON TRIANGLE MATERIALS THROUGH STAD COOPERATIVE LEARNING MODEL
}

\author{
Hery Setiyawan \\ Universitas Wijaya Kusuma Surabaya \\ Hery_deathschyte@yahoo.co.id
}

\begin{abstract}
Abstrak
Jenis penelitian ini adalah penelitian deskriptif dengan pendekatan kualitatif. Penelitian ini dilaksanakan di kelas VII-A SMPN 2 Balongbendo semester genap tahun ajaran 2018/2019 dengan jumlah siswa 33 orang. Data interaksi belajar siswa dalam kelompok diperoleh dengan lembar observasi, sikap konstruktif siswa diperoleh dari angket. Berdasarkan analisis data, dapat disimpulkan bahwa interaksi belajar matematika siswa dalam pembelajaran kooperatif yang terjadi dalam menyampaikan ide atau pendapat yaitu sebesar $53,8 \%$ untuk kelompok 1 dan $46,7 \%$ untuk kelompok 2 , memberi bantuan yang disertai dengan penjelasan sebesar 15,4\% untuk kelompok 1 dan 20,0\% untuk kelompok 2, memberi bantuan tanpa disertai pejelasan sebesar $15,4 \%$ untuk kelompok 1 dan 13,3\% untuk kelompok 2, dan interaksi belajar matematika siswa dalam meminta bantuan sebesar 15,4\% untuk kelompok 1 dan 20,0\% untuk kelompok 2. Sikap konstriktis siswa dengan menerapkan model pembelajaran kooperatif tipe STAD menunjukkan mayoritas siswa mempunyai sikap konstruktif terhadap matematika yang cukup bagus yaitu sebanyak 24 siswa dari 33 siswa.
\end{abstract}

Kata kunci: interaksi belajar, sikap, kooperatif tipe STAD, segitiga.

\begin{abstract}
The type of this research is descriptive research with qualitative approach. This research was done in class of VII-A SMPN 2 Balongbendo in second semester 2018/2019. There are thirty three students in that class. The data of students learning interaction were got from observation sheet and note and students' constructive attitudes were got from questionnaire. Based on data analysis can be concluded that the interaction of students Mathematics learning in cooperative learning in case of delivering idea or opinion is $53,8 \%$ for first group and $46,7 \%$ for second group. In case of giving a help with some explanations is $15,4 \%$ for first group and $20,0 \%$ for second group. In case of giving a help without some explanations is $15,4 \%$ for first group and $13,3 \%$ for second group. In case of asking a help is $15,4 \%$ for first group and $20,0 \%$ for second group. Students' constructive attitudes by using STAD type of cooperative learning show that most of students have quite good constructive attitudes about Mathematics that is twenty four of thirty three students.
\end{abstract}

Keywords: learning interaction, attitude, STAD cooperative, triangle.

Sitasi: Setiyawan, H. 2019. Interaction of Learning Mathematics and Constructive Attitudes of Students on Triangle Materials Through STAD Cooperative Learning Model. Matematika dan Pembelajaran, 7(1), 91-101. 


\section{INTRODUCTION}

Mathematics as one of the basic sciences, both its applied aspects and its reasoning aspects, has an important role in the effort to master science and technology. For this reason, school mathematics needs to be functioned as a vehicle to develop intelligence, abilities, skills, and to shape the personality of students. The purpose of learning mathematics in forming traits includes developing rational, critical, and creative mindsets, and forming constructive attitudes. According to R. Soetarno (in Ulfah.2005: 23), "constructive attitude is the attitude of someone whose implementation is in the form of action or behavior that is not detrimental to both himself and others". The aspect of constructive attitude is students 'happy attitude towards the lesson, students' curiosity towards the lesson, and the attitude of wanting to help friends who have difficulty in learning. For this reason, teachers need to pay attention to the imagination and curiosity of students in learning. Teachers should choose and use strategies, approaches, methods, and techniques that involve students to be active in learning both physically, mentally and socially.

Mathematical learning that has seemed to involve only the process of transferring facts from the teacher to students solely needs to be eliminated. Students should be actively involved in fostering concepts and knowledge related to each of the contents of the lesson learned. Students need to set their reasoning, shape their personalities, and be able to use or apply mathematics in their lives according to their level of education. Changes in ways and systems in the teaching and learning process in schools will affect the attitudes and learning habits of students. Russefendi (1980: 131) states that, "A positive attitude towards mathematics makes students understand mathematics, seeing mathematics is beautiful and such an attitude will encourage students to learn it".

One alternative to student-centered learning or learning that involves student activity and makes it possible to work together is learning that uses cooperative learning models. Cooperative learning can increase student activity and make it easier for students to interact with each other in helping other students in achieving learning goals. The process of learning mathematics is not always effective, because 
there are still some students who have difficulty learning mathematics. Mathematical learning difficulties are mainly due to the special nature of mathematics which has abstract objects. It is this nature that needs to be realized and a way out so students can learn mathematics easily and pleasantly.

The low motivation of students resulted in a curiosity towards mathematics and a sense of solidarity between students in learning mathematics became reduced, plus difficult subject matter and less interesting learning process made students less appreciate the usefulness of mathematics. For this reason, researchers applied a cooperative learning model. It is expected that cooperative learning can encourage active students to determine their own knowledge through process skills, and can increase student activity and facilitate students to interact with each other in helping other students so that constructive attitudes and interactions of students in mathematics learning are expected to increase which in turn will have a positive effect namely the increase in student mathematics learning outcomes and mastery of concepts and skills. In group learning, it is expected that group members are able to achieve mastery learning and help each other between group members to achieve this completeness. One type of cooperative learning model is STAD (Student Team Achievement Division). In mathematics learning, the STAD type cooperative learning model centered on students who collaborate in one group is expected to help students improve positive attitudes and constructive attitudes, as well as interactions in learning mathematics. The scope of mathematics subjects in junior high school / MTs education units that must be mastered by students of class VII Junior High School is one of them about geometry and measurement. In this study, the material taken was triangular material.

In accordance with the description stated above, this study aims to describe students' mathematics learning interactions during STAD type cooperative learning on Triangle material and also constructive attitudes of students towards mathematics with the STAD type cooperative learning model on Triangle material.

A person's attitude towards an object is strongly influenced by the environment in which he is located. A person's attitude towards a lesson is also influenced by a number of things such as teachers, school environment, home 
environment, friends and so on. The action taken is in the form of behavior called attitude. The behavior in question can be in the form of opinions, similarities, expressions or physical actions such as helping or rebelling.

According to Ahmadi (1982: 91) "attitude functions to adjust, regulate behavior, experience management tools, and statement of personality". Adolescence is a transition period between childhood to adulthood, this lasts from the age of 13 years to 18 years. At this time the child begins to have a sense of pleasure towards something, has the curiosity to try something, the desire to cooperate and a willingness to accept something that is needed by others.

According to Soetarno Cigarettes (in Ulfah.2005: 23), "constructive attitude is the attitude of a person whose implementation is an act or behavior that is not detrimental to both himself and others". Shapiro (Wirawan.1983: 42), states that the purpose of knowing something is not to find reality, but to organize "knowledge" that matches the experience of human life, so that it can be used when dealing with challenges and new experiences.

The constructive attitude of students towards mathematics will help understand and master social, economic and natural problems, because mathematics teaches a systematic and high-minded mindset. So constructive attitude will encourage and help students face all kinds of problems in the era of globalization.

"In general, interactions can be interpreted as communication or reciprocal relations between two or more people for certain purposes" (Roestiyah, 1994: 35). Interactions that occur during the learning process take place to achieve educational goals are called learning interactions. According to Suprayekti (2003: 4), learning interaction is an interactive activity of various components to realize the learning objectives that have been set when planning learning.

The main elements directly involved in the learning interaction process are the teacher, students, and subject matter. The teacher acts as a facilitator that facilitates the learning process by creating conditions that encourage students to learn actively in learning activities. While students are subjects who learn to achieve learning goals. The subject matter is an intermediary between interactions between teachers and students and students with students. 
Based on the learning objectives of mathematics that students who are capable are not only able to solve problems and reasons mathematically, but also become confident and communicate them effectively and create relationships between mathematics and other aspects of life. To achieve that goal, a learning strategy is needed that can accommodate student interactions with the learning environment. One of the learning strategies according to Vygotsky that supports this is teaching strategies that use collaborative groups, providing opportunities for interaction between students.

In the learning process Slavin (2005: 34) suggests that teachers create a conducive learning environment, encourage students to be creative, solve problems and encourage students to discuss differences of opinion by reducing the pressure on students' responses that are not appropriate. This if applied in mathematics learning as a process of construction and abstraction of mathematical concepts by maximizing mathematical problem solving, can be achieved through cooperative learning as stated by Vygotsky that problem-solving performance will be achieved at a higher level if the child works in cooperative groups, especially heterogeneous (Ratumanan, 2004: 21).

In this study, the interaction of students' mathematics learning in STAD type cooperative learning in assignments was to provide assistance, ask for help, and convey ideas / opinions.

STAD type learning is one among cooperative learning models. The cooperative learning model is a practical class technique that can be used by the teacher every day to help students learn each subject, from basic skills to complex problem solving.

"Learning systems that provide opportunities for students to cooperate with fellow students in structured tasks are referred to as cooperative learning systems" (Lie, 2002: 22). STAD type cooperative learning steps, namely preparation, learning stage and independent evaluation and group awards 


\section{METHOD}

This type of research is descriptive research. This study aims to describe the symptoms of phenomena that are systematically and carefully examined to produce factual and accurate data that are truly natural (Suryabrata, 2004: 75). The approach used in this study is a qualitative approach. In this study, it will be described about the interaction of students' mathematical learning and constructive attitudes of students in STAD type cooperative learning.

The subjects of this study were students of class VII-A of Balongbendo Junior High School 2 Sidoarjo with 33 students consisting of 13 men and 20 women because the mathematics subject teachers gave advice to conduct research in class VII-A.

The research design used was "One shot case study". In this study, the instruments used were the Student Mathematics Learning Interaction Learning sheet and Questionnaire Student's constructive attitude questionnaire. In collecting data used observation methods and questionnaire methods. Data from student observations were analyzed by describing students' mathematical learning interaction data with steps:

a) Read and study all data obtained from the observation sheet on the interaction of students' mathematics learning in groups that has been done to find out and record student learning interactions that occur.

b) Analyze, examine, and summarize data on the results of students' mathematics learning interactions.

c) Data Presentation / Exposure

d) Withdrawal Conclusion

Based on the analysis, interpretations were carried out to obtain conclusions. Research is considered complete if conclusions have been completed and answered the research question. 


\section{RESULT AND DISCUSSION}

In this study researchers only observed 2 groups, namely group 1 and group 2. The results of observations that have been made, the data obtained in the study of mathematical learning interactions of students of class VII-A Balongbendo Junior High School 2 in group 1 showed that the percentage of student learning interactions giving assistance accompanied by an explanation was $15.4 \%$ and $15.4 \%$ for interaction giving assistance without explanation. While the percentage of student learning interactions in asking for help is $15.4 \%$ and $53.8 \%$ for interactions conveying ideas or opinions. The results of observations made in group 2 show that the percentage of student learning interactions in giving assistance accompanied by an explanation is $20.0 \%$ and $13.3 \%$ for interactions providing assistance without explanation. While the percentage of student learning interactions in asking for help is $20.0 \%$ and $46.7 \%$ for interactions conveying ideas or opinions.

The results of the analysis of students' mathematics learning interactions in cooperative learning STAD type are based on the results of the observation sheet. Observations are made when students work in groups. Students interact with members in their groups to discuss Student Worksheets that have been given by researchers. Observation results of students' mathematical interactions that often occur in STAD type cooperative learning in group 1 are interactions in terms of conveying ideas or opinions. This tends to be dominated by highly skilled students. Students with moderate ability and low-ability students also do so with less frequency than high-ability students. High-ability students are more dominant interacting to provide assistance to other students both with explanations and without explanation and for low-ability students who are more dominant interacting asking for help. Similarly, the results of observations in group 2, the results are not much different from group 1.

Observation data obtained were analyzed to determine the interaction patterns of mathematics learning of students in STAD type cooperative learning, namely the dominant tendency and the number of student activities in groups 1 and 2 related to 
students' mathematics learning interactions while completing student worksheets in groups. For this reason, a description of student learning interactions will be discussed based on the following components (categories):

a) Give help with explanation.

Based on the results of the study, the interaction of giving was accompanied by an explanation of the frequency as much as 5. In group 1, interaction giving assistance was accompanied by an explanation of $15.4 \%$. While the interaction of giving assistance accompanied by explanations in group 2 is $20.0 \%$. This was caused partly because in the first meeting students were not accustomed to working in groups so that there were still many students who did not understand the assignments given which resulted in other students having to provide assistance accompanied by explanations. Whereas in the second meeting students who were able to get used to learning in groups because of the experience of the previous meeting so that the interaction to provide assistance accompanied by explanations diminished.

b) Give assistance without explanation

Based on an analysis of dialogue between students in the group, it appears that there is a tendency that high-ability students are more likely to provide assistance accompanied by explanations to students with moderate ability and low-ability students so that low-ability students are more likely to be assisted by high-ability students.

c) Ask for help

Based on the analysis of dialogue between students in groups, Based on the description above, it appears that there is a tendency that students who convey ideas or opinions are more often carried out by students who are highly skilled and the ideas delivered are immediately followed by other students, both moderate and low-ability students. .

From the description shows that STAD type cooperative learning can to train students' skills to express ideas or opinions in front of other students. So it is in accordance with the theory put forward by Vigotsky and Slavin that cooperative learning can make students active during learning. 
The data in this study are presented in descriptive form where the researcher describes constructive attitudes of students after applying the cooperative learning model on the subject of the triangle. The constructive attitude data of the students was obtained from constructive attitude questionnaires of students, this questionnaire consisted of 20 problems that students must answer honestly. This questionnaire is given at the end of learning to determine the level of constructive attitudes of students towards mathematics. From the results of the study, it was found that there were 0 students who were not good criteria, who received poor criteria as many as 8 students, who got quite good criteria as many as 24 students, and who got good criteria only 1 student. So, most students of class VII-A in Balongbendo Junior High School 2 have constructive attitudes which are said to be quite good because the majority get quite good criteria, which is 24 students.

\section{CONCLUSION}

Based on the objectives of the study, data analysis and discussion of the results of the study it can be concluded that:

1. Mathematical learning interactions of class VII-A students at Balongbendo Junior High School 2 in STAD type cooperative learning in terms of:

a. Giving assistance accompanied by explanations tends to be carried out by high-ability students and the percentage is $15.4 \%$ for group 1 and $20.0 \%$ for group 2.

b. Giving assistance without being accompanied by explanations tends to be done by high-ability students and the percentage is $15.4 \%$ for group 1 and $13.3 \%$ for group 2 .

c. Requesting assistance tends to be carried out by students with low ability and the percentage is $15.4 \%$ for group 1 and $20.0 \%$ for group 2 .

d. Delivering dominant ideas is carried out by high-ability students and the percentage is $53.8 \%$ for group 1 and $46.7 \%$ for group 2 .

2. The constructive attitude of students in the majority of mathematics learning is quite good because of 33 students who get the bad criteria as many as 0 
students, who get poor criteria as many as 8 students, who get quite good criteria as many as 24 students, and who get good criteria only 1 student .

Based on the results of the research obtained, the researcher gave several suggestions as follows:

1. Should the next study, researchers pay more attention to and direct student learning interactions that occur in the classroom so that the interaction that occurs is not only dominated by students who are highly capable but also other students.

2. Should the next study, researchers facilitate or encourage students with moderate and low ability to actively interact in classroom learning, by more often practicing their skills in conveying ideas in front of the class.

3. Teachers as educators and instructors provide direction to students and manage interesting mathematical learning so that students have a happy attitude towards mathematics, and have the attitude to help friends who have difficulty learning mathematics.

\section{REFERENCE}

Ahmadi, Abu. (1982). Psikologi Sosial. Surabaya: Bina Ilmu

Lie, A. (2002). Cooperative Learning, Mempraktikkan Cooperative Learning diruang-ruang kelas. Jakarta:Grassindo.

Ratumanan, Tanwey, Gerson. (2004). Belajar Dan Pembelajaran. Surabaya: Unesa University Press.

Roestiyah, NK. (1994). Masalah Pengajaran Sebagai Suatu Sistem. Bandung: Rineka Cipta.

Russefendi. (1980). Pengajaran matematika untuk sekolah menengah. Jakarta: Depdikbud.

Slavin, Robert. (2005). Cooperative Learning. (Terjemahan Lita). Bandung: Nusa Media.

Suprayekti. (2003). Interaksi Pembelajaran. Jakarta: Depdiknas.

Suryabrata, Sumadi. (2004). Metodelogi Penelitian. Jakarta: Raja Grafindo Persada.

Ulfah, Ida Fitriana. (2005). Meningkatkan Hasil Belajar Dan Sikap Konstruktif Terhadap Pembelajaran Waktu, Jarak, Dan Kecepatan Melalui Model Pembelajaran Kooperatif Stad (Student Team Achievement Division) Pada Siswa Smpn 2 Demak Tahun 2004/2005 (Online). (http://digilib.unnes.ac.id/gsdl/collect/skripsi/archives/HASH0ccb/739def00.d ir/doc.pdf, diakses 01 April 2019). 
Setiyawan, H. 2019. Interaction of Learning Mathematics... Matematika dan Pembelajaran, 7(1), 101 of 101

Wirawan, Sarlito. (1983). Teori Spikologi Sosial. Jakarta: Rajawali. 